\title{
MORPHOLOGICAL AND ULTRASTRUCTURAL STUDIES OF PLANT

\author{
CUTICULAR MEMBRANES. I. SUN AND SHADE LEAVES OF
} QUERCUS VELUTINA (FAGACEAE)
}

\author{
JEFFREY M. OSBORN AND THOMAS N. TAYLOR
}

Department of Plant Biology, Ohio State University, Columbus, Ohio 43210

\begin{abstract}
Sun and shade leaves of Quercus velutina Lam. were evaluated with respect to differences in gross anatomy, morphology, and cuticle (cuticular membrane $[\mathrm{CM}]$ ) ultrastructure and micromorphology. Sun leaves are smaller, with more deeply lobed margins, and have more stomata, thicker mesophylls, and thicker CMs when compared with shade leaves. Cuticular membranes are thicker on both the adaxial and abaxial surfaces of sun leaves as a result of deposition of more cuticular components and scaly epicuticular wax. Both the adaxial and abaxial epidermises have the same basic fine structure in sun and shade leaves with respect to the outer periclinal cell wall and overlying CM. The cell wall is lamellate and the CM is composed of a two-zoned, reticulate cuticular layer and an amorphous cuticle proper. The outer periclinal wall and associated $\mathrm{CM}$ of the adaxial epidermis is thicker than that of the abaxial epidermis with both epidermal layers thicker in sun leaves compared with shade leaves. Difference in thickness of both epidermal layers, between sun and shade leaves, can be attributed to an increase in the inner reticulate region of the CM of sun leaves. Cells of the abaxial epidermis have ultrastructurally different CMs. Nonstomatal epidermal cells have a distinct amorphous cuticle proper whereas subsidiary cells have reticulations that traverse most of the outer $\mathrm{CM}$. Guard cells have radially aligned reticulations through the entire outer CM and, therefore, lack an amorphous cuticle proper. Moreover, an internal CM, which is only sparsely reticulate, lines substomatal chambers. The internal $\mathrm{CM}$ of sun leaves is thicker and extends considerably deeper into substomatal chambers.
\end{abstract}

\section{Introduction}

Cuticles are particularly prominent on leaves because these organs function primarily in photosynthesis and consequently receive a significant amount of solar radiation. Numerous broad-leafed tree species exhibit environmental leaf morphotypes, including so-called sun and shade leaves, which develop under different light regimes. Sun leaves develop at the top of the tree crown where they are exposed to ambient sunlight, while shade leaves form in the interior canopy and receive only intermittent periods of high irradiances, or sun flecks. In general, sun leaves are smaller, with more deeply lobed margins, often with more pubescent blades, and are characterized by greater numbers of stomata per square mm. Mesophyll tissues (particularly palisade parenchyma) and cuticles are also thicker in sun leaves (ESAU 1965).

Irradiance level and its relative effect on sun and shade leaves have been investigated from different perspectives both in natural populations and in plants grown under controlled conditions. Overall leaf morphology, e.g., size and lobing, has been demonstrated to differ for outer sun and inner shade leaves (BLUE and JENSEN 1988) and when correlated with crown geometry indicates that sun and shade leaves are well adapted for a multilayered

Manuscript received February 1990; revised manuscript received May 1990.

Address for correspondence and reprints: JEFFREY M. OsBORN, Department of Plant Biology, Ohio State University, 1735 Neil Avenue, Columbus, Ohio 43210-1293. leaf distribution (HoRN 1971). NIKLAS (1989), however, has more recently shown that the probability of light interception by shade leaves is actually equal to or greater than sun leaves, primarily due to less leaf overlap of the former. Sun leaves have also been shown typically to have higher stomatal densities (SOLÁROVÁ and PospíšIlLOVÁ 1988) as well as increased lengths of stomatal pores (WILD and WOLF 1980). Although more stomata per unit area on sun leaves provides a greater probability for transpiration, VOGEL (1968) has shown that sun leaves are better adapted for heat dissipation, based on their morphology.

In general, sun leaves have a greater capacity for fixing $\mathrm{CO}_{2}$ (BJÖRKMAN 1981); however, the effects of shading have recently been shown to increase surface areas of thylakoid membranes and thus increase light-gathering potential (FAGERBERG 1988). It has also been suggested that the synthesis of cellulosic and pectic substances in the outer periclinal walls of epidermal cells is intensified under higher irradiances (GIULINI-CORDERA 1970). KAUSCH and HAAS (1965) report that the overall chemical makeup of sun and shade leaves are proportionally different: sun leaves have more cutin relative to constituent amounts of cellulosic matierals. Furthermore, ESPELIE et al. (1979) found differences among the proportions of specific positional isomers of cutin in leaves grown at different irradiances. Cuticular waxes also increase in amount with an increase of irradiance (TRIBE et al. 1968). Higher irradiances are further known to induce the deposition of substantially more epicuticular waxes on leaf surfaces 
(BAKER 1974), and affect the orientation of individual wax platelets (HuLl et al. 1979).

Anatomical differences between sun and shade leaves have been known for many years (HANSON 1917; DENGLER 1980) with sun leaf cuticles being reported as generally thicker when observed with light microscopy (MARTIN and JUNIPER 1970). Few studies, however, have addressed the structural aspects of plant cuticles that develop under different light regimes using electron microscopic techniques. Hull et al. (1975) and REED and TuKEY (1982) compared cuticles that were experimentally subjected to combined irradiance and temperature treatments. Both studies found that cuticle thickness was more significantly affected by changes in temperature than by light and that lower temperatures induced thicker cuticles. Moreover, when irradiance was varied within both high and low temperature treatments, plants exposed to low light conditions in all treatments produced thicker cuticles.

In the present study, we assessed cuticular differences between sun and shade leaves from Quercus velutina Lam. (Fagaceae) at the ultrastructural and micromorphological levels, using transmission and scanning electron microscopy.

\section{Material and methods}

\section{Plant MATERIAL}

Sun and shade leaves were collected from a single individual of Quercus velutina (Black Oak) growing under natural conditions. Sun leaves were obtained from an upper, peripheral position in the crown at a height of ca. $7 \mathrm{~m}$ where they were fully exposed to sunlight. Shade leaves were collected from a site ca. $3 \mathrm{~m}$ under the canopy. Fully expanded leaves from the first and fourth nodes of each environmental type were examined.

\section{LIGHT MICROSCOPY}

Leaf tissue was removed from both lateral and medial positions on the blades and fixed for $24 \mathrm{~h}$ in $6.3 \%$ glutaraldehyde in sodium cacodylate buffer ( $\mathrm{pH}$ 6.5). The fixed tissue was washed in buffer, dehydrated in a graded ethanol series, transferred to $100 \%$ acetone, gradually infiltrated with Spurr low viscosity epoxy resin, and embedded flat to ensure true transverse sectioning. Thin transverse sections $(0.5 \mu \mathrm{m})$ were cut with an American Op- tical (AO) Ultracut ultramicrotome using glass knives, mounted on glass microscope slides, and stained with toluidine blue. Isolated cuticles, or cuticular membranes (CMs - cuticular layer, or cutinized outer wall, and cuticle proper [see HoLLOWAY 1982]), were obtained by placing fresh, intact leaf specimens in $10 \%$ chromium trioxide for $24 \mathrm{~h}$ (ALVIN and BOULTER 1974) and photographed along with thin sections on a Zeiss Ultraphot light microscope (LM). Stomatal densities were determined by placing $\mathrm{CM}$ isolates on a hemacytometer.

\section{TRANSMISSION ELECTRON MICROSCOPY}

Leaf tissue was fixed, dehydrated, infiltrated, and embedded as for light microscopy. Prior to dehydration, however, the tissue was post-fixed in buffered $1 \%$ osmium tetroxide for $2 \mathrm{~h}$ and washed with buffer. Ultrathin transverse sections were prepared on an AO Ultracut ultramicrotome with a diamond knife, collected on uncoated copper slot grids, and dried onto formvar support films (ROWLEY and MORAN 1975). Grids were stained with $1 \% \mathrm{KMnO}_{4}$ (0-20 $\mathrm{min}), 1 \%$ uranyl acetate $(20-30 \mathrm{~min})$, and

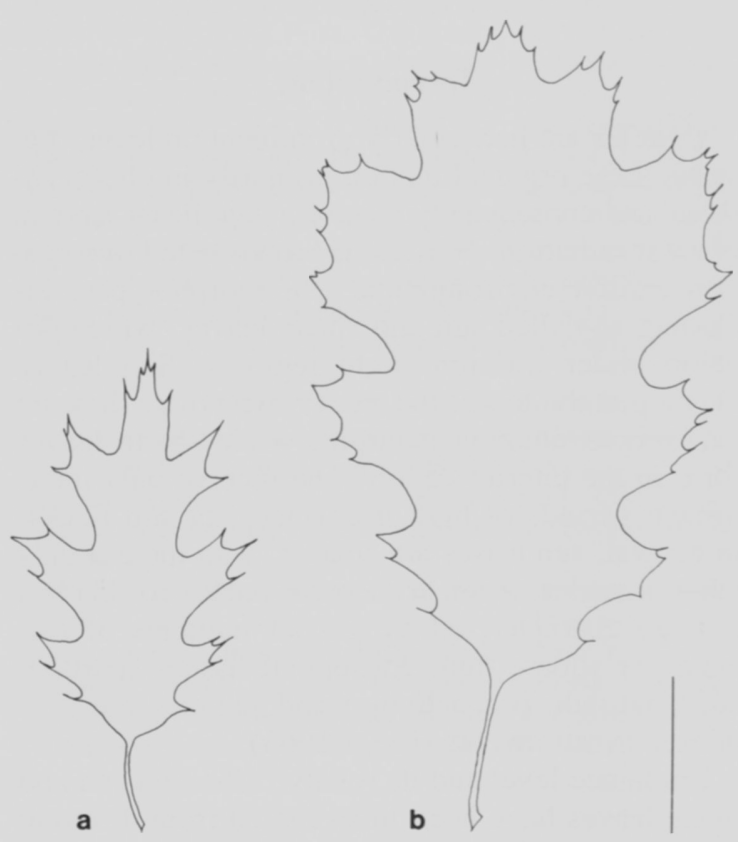

FIG. 1.-General morphology of sun $(a)$ and shade $(b)$ leaves from Quercus velutina. Scale bar, $5 \mathrm{~cm}$.

Figs. 2-9.- Light and scanning electron micrographs of laminal anatomy and the adaxial epidermis of sun and shade leaves from Quercus velutina (sun leaves: figs. 2, 4, 6, and 8; and shade leaves: figs. 3, 5, 7, and 9). Fig. 2, Transverse section through lateral lamina of sun leaf; note thick palisade parenchyma tissue. Scale bar, $75 \mu \mathrm{m}$. Fig. 3, Transverse section through lateral lamina of shade leaf; note equal distribution of palisade and spongy parenchyma tissues. Scale bar, $75 \mu \mathrm{m}$. Fig. 4, Transverse section of sun leaf showing thick CM. Scale bar, $10 \mu \mathrm{m}$. Fig. 5, Transverse section of shade leaf showing thin CM. Scale bar, $10 \mu \mathrm{m}$. Fig. 6, Surface morphology of sun leaf CM; note smooth topography and presence of epicuticular wax. Scale bar, 20 $\mu \mathrm{m}$. Fig. 7, Surface morphology of shade leaf CM. Corrugated appearance results from anticlinal walls of underlying epidermal cells and relative absence of epicuticular wax. Scale bar, $20 \mu \mathrm{m}$. Fig. 8, Inner surface of isolated sun leaf CM with thick anticlinal flanges $(F)$ and distinct cuticular pegs (arrow). Scale bar, $20 \mu \mathrm{m}$. Fig. 9, Inner surface of isolated shade leaf CM showing thin anticlinal flanges and less prominent cuticular pegs. Scale bar, $20 \mu \mathrm{m}$. 


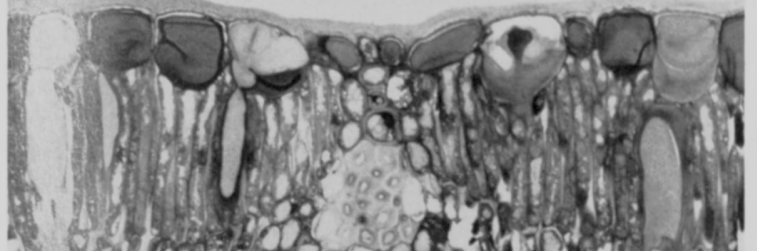

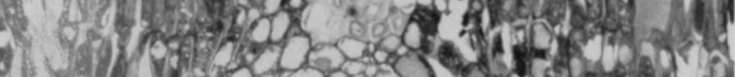

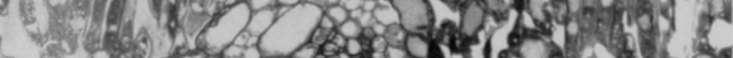

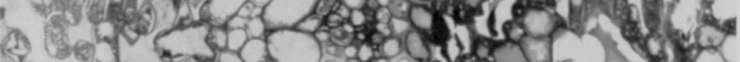

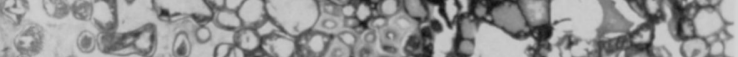

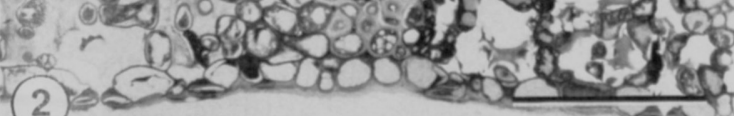

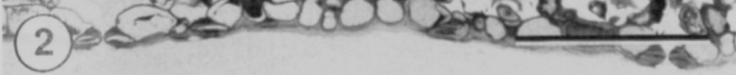
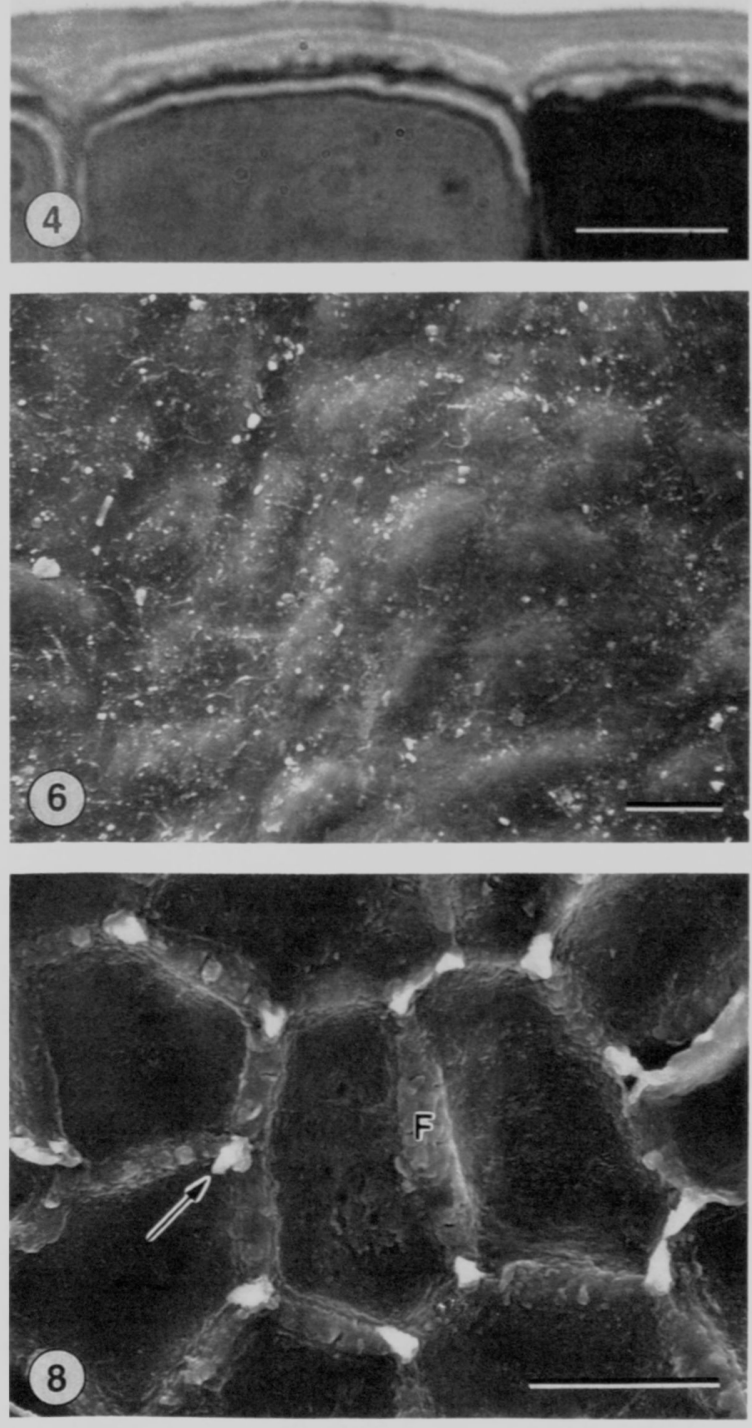
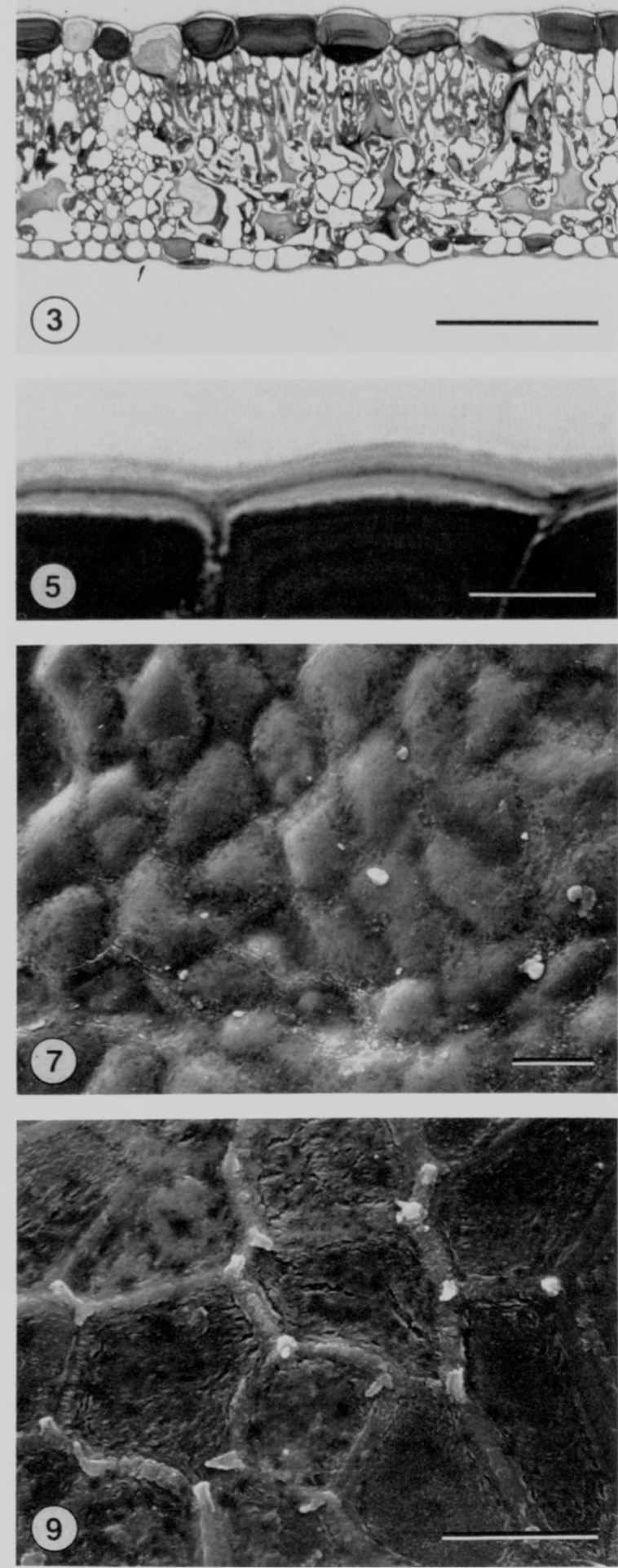
lead citrate (10-30 min [Venable and CogGESHALL 1965]), and carbon coated. Images were recorded using a Zeiss EM-10 transmission electron microscope (TEM) at $60-80 \mathrm{kV}$.

\section{SCANNING ELECTRON MICROSCOPY}

Leaf tissue was fixed, to observe outer CM surfaces, and oxidized in chromium trioxide, to observe inner CM surfaces, as for light microscopy, air dried, and mounted on aluminum stubs. Aluminum stubs were sputter coated with gold-palladium and images recorded on a Hitachi S-500 scanning electron microscope (SEM) at $20 \mathrm{kV}$.

\section{Results}

\section{GROSS MORPHOLOGY AND ANATOMY}

Sun leaves are relatively small and have deeply lobed margins (fig. 1a), while the laminae of shade leaves are generally 1.5 times longer and exhibit shallow sinuses (fig. $1 b$ ). On average, sun leaves are ca. 1.6 times thicker than shade leaves, 189 $\mu \mathrm{m}$ and $117 \mu \mathrm{m}$ in thickness, respectively (figs. 2, 3 ; table 1). The difference in lamina thickness is primarily due to an increased amount of palisade parenchyma in sun leaves. Palisade tissue is more than twice the thickness of spongy parenchyma in sun leaves, whereas they occur in about the same proportions in shade leaves (table 1).

\section{ADAXIAL EPIDERMIS}

Adaxial epidermal cells from both leaf types are tabular and basically the same size in anticlinal width, although the epidermal cells of sun leaves are deeper periclinally (figs. 2, 3; table 1). Light microscopy also reveals that the CM is thicker in sun leaves (fig. 4) when compared with shade leaves (fig. 5).

The surface morphology of sun leaves appears smoother, due in part to more epicuticular wax (fig. 6 ), while the outer surface of shade leaf CMs exhibits more topographic relief, with individual epidermal cells appearing distinct (fig. 7). The internal surface of the $\mathrm{CM}$ from sun leaves shows a relatively deep morphology, while it is more shallow in shade leaves (figs. 8, 9). Moreover, CM anticlinal flanges are thicker in sun leaves, and cuticular pegs-material between anticlinal walls of contiguous epidermal cells-are more distinct in sun leaves as well (figs. 8, 9).

TABLE 1

ANATOMICAL AND ULTRASTRUCTURAL FEATURES OF QUERCUS VELUTINA SUN AND SHADE LEAVES

\begin{tabular}{|c|c|c|}
\hline $\begin{array}{c}\text { Structural feature } \\
\text { (transverse thickness) }\end{array}$ & $\begin{array}{c}\text { Sun leaf } \\
(\text { mean } \pm \mathrm{SD}[\mu \mathrm{m}])^{a}\end{array}$ & $\begin{array}{c}\text { Shade leaf } \\
(\text { mean } \pm \mathrm{SD}[\mu \mathrm{m}])^{\mathrm{a}}\end{array}$ \\
\hline Entire blade . & $188.94 \pm 5.39$ & $116.88 \pm 5.80$ \\
\hline \multicolumn{3}{|l|}{ Mesophyll: } \\
\hline Palisade parenchyma $\ldots \ldots \ldots \ldots \ldots \ldots$ & $105.30 \pm 5.94$ & $48.36 \pm 4.41$ \\
\hline 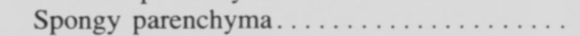 & $47.44 \pm 4.22$ & $47.32 \pm 4.51$ \\
\hline \multicolumn{3}{|l|}{ Adaxial epidermis: } \\
\hline Anticlinal width & $29.60 \pm 2.80$ & $31.06 \pm 4.66$ \\
\hline Periclinal depth ........ & $31.66 \pm 7.53$ & $22.84 \pm 1.94$ \\
\hline \multicolumn{3}{|l|}{ Outer periclinal wall: } \\
\hline Wall and cuticular membrane ........... & $5.94 \pm .47$ & $2.68 \pm .13$ \\
\hline 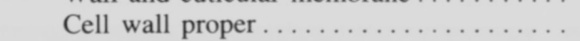 & $1.14 \pm .09$ & $1.02 \pm .08$ \\
\hline \multicolumn{3}{|l|}{ Cuticular membrane: } \\
\hline Reticulate region $\ldots \ldots \ldots \ldots \ldots \ldots$ & $4.24 \pm .53$ & $1.40 \pm .12$ \\
\hline Cuticle proper $\ldots \ldots \ldots \ldots \ldots \ldots$ & $.82 \pm .13$ & $.37 \pm .06$ \\
\hline \multicolumn{3}{|l|}{ Abaxial epidermis: } \\
\hline \multicolumn{3}{|l|}{$\begin{array}{c}\text { Nonstomatal epidermal cells and } \\
\text { subsidiary cells: }\end{array}$} \\
\hline Anticlinal width . . . . . . . . . . & $21.26 \pm 6.24$ & $16.12 \pm 1.64$ \\
\hline Periclinal depth . ................ & $14.74 \pm 2.58$ & $10.00 \pm 1.07$ \\
\hline \multicolumn{3}{|l|}{ Outer periclinal wall: } \\
\hline Wall and cuticular membrane ........ & $4.44 \pm .18$ & $2.94 \pm .11$ \\
\hline Cell wall proper .................. & $.88 \pm .13$ & $.89 \pm .07$ \\
\hline \multicolumn{3}{|l|}{ Cuticular membrane: } \\
\hline Reticulate region $\ldots \ldots \ldots \ldots \ldots$ & $3.44 \pm .24$ & $2.06 \pm .11$ \\
\hline Cuticle proper $\ldots \ldots \ldots \ldots \ldots$ & $.16 \pm .04$ & $.12 \pm .03$ \\
\hline \multicolumn{3}{|l|}{ Guard cells: } \\
\hline Anticlinal width $\ldots \ldots \ldots \ldots \ldots \ldots$ & $9.92 \pm .96$ & $9.68 \pm .57$ \\
\hline Periclinal depth $\ldots \ldots \ldots \ldots \ldots \ldots \ldots$ & $9.36 \pm .37$ & $8.98 \pm .61$ \\
\hline Outer periclinal wall, cuticular membrane & $1.01 \pm .17$ & $.65 \pm .05$ \\
\hline Inner cuticular membrane $\ldots \ldots \ldots \ldots$ & $.26 \pm .04$ & $.14 \pm .02$ \\
\hline
\end{tabular}

${ }^{\mathrm{a}}$ No. $=5$. 

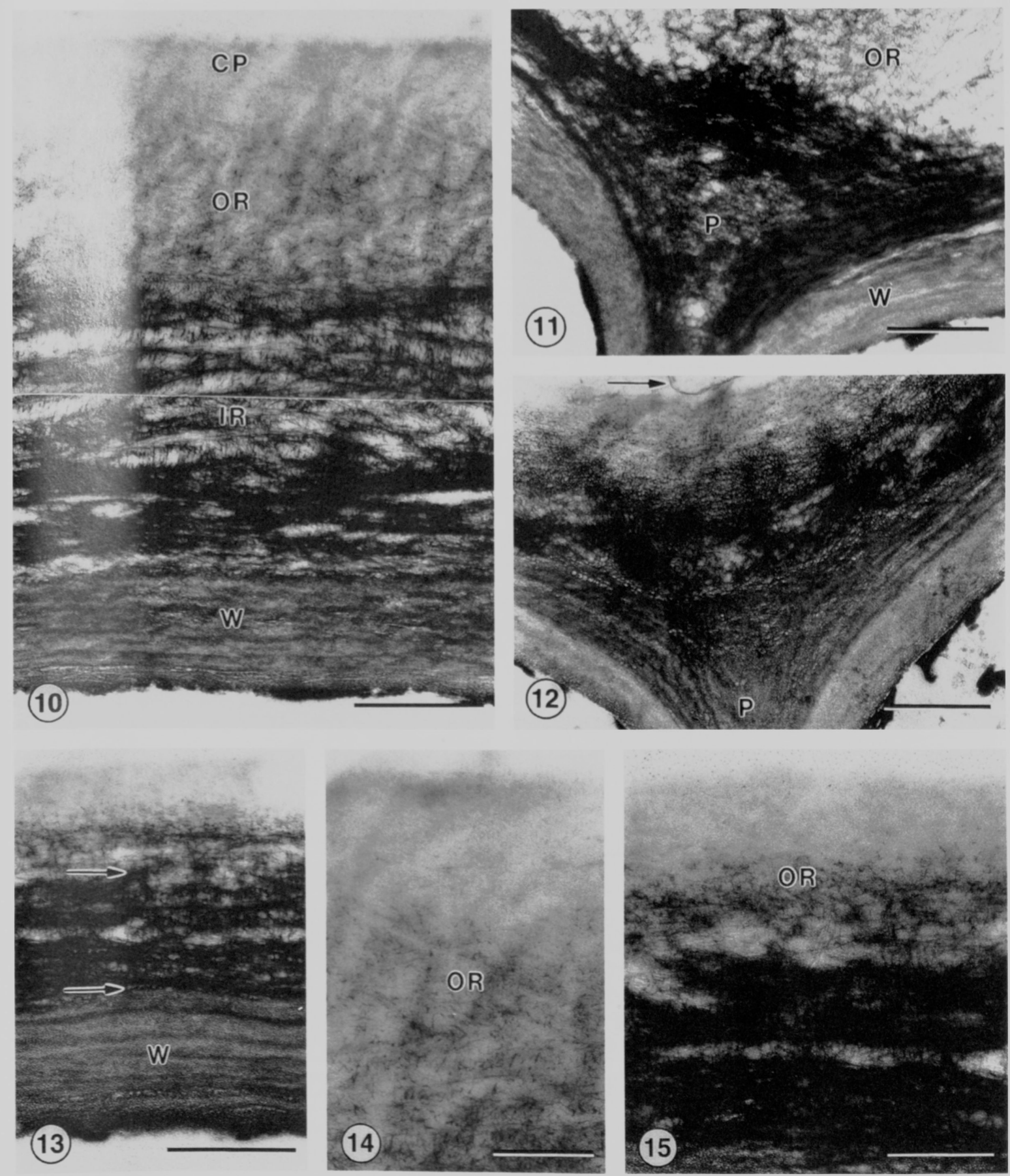

FIGS. 10-15. - Transmission electron micrographs of the adaxial epidermis of sun and shade leaves from Quercus velutina (sun leaves: figs. 10, 11, and 14; and shade leaves: figs. 12, 13, and 15). Fig. 10, Transverse section of outer periclinal wall and CM of sun leaf showing lamellate cell wall proper $(W)$, cuticular layer of inner densely reticulate region $(I R)$ and outer sparsely reticulate region $(O R)$, and amorphous cuticle proper $(C P)$. Scale bar, $1 \mu \mathrm{m}$. Fig. 11, Transverse section of two outer periclinal walls at junction with anticlinal wall of sun leaf. Lamellae of cell wall proper $(W)$ are continuous between periclinal and anticlinal walls; note excessive inner reticulate region forming cuticular peg $(P)$, and thick outer reticulate region $(O R)$, which extends beyond edge of micrograph. Scale bar, $1 \mu \mathrm{m}$. Fig. 12, Transverse section of two outer periclinal walls at junction with anticlinal wall of shade leaf. Note reduction of the inner reticulate region that forms the cuticular peg $(P)$, and thinner outer reticulate region, cuticle proper, and epicuticular wax (arrow). Scale bar, $1 \mu \mathrm{m}$. Fig. 13, Transverse section of outer periclinal wall and CM of shade leaf. Compare lamellate organization and thickness of cell wall proper $(W)$ and reticulate regions, particularly the inner densely reticulate zone (between arrows), with sun leaf. Scale bar, $1 \mu \mathrm{m}$. Fig. 14, Detail of amorphous cuticle proper and cuticular layer from sun leaf; note limit of fibrils within the outer reticulate zone $(O R)$. Scale bar, $0.5 \mu \mathrm{m}$. Fig. 15, Detail of amorphous cuticle proper and cuticular layer from shade leaf; note compressed outer reticulate zone $(O R)$. Scale bar, $0.5 \mu \mathrm{m}$. 
9,42

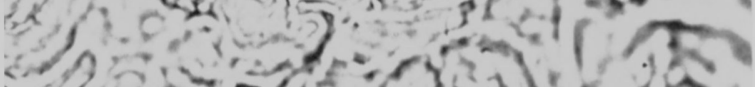
of 430 (1)

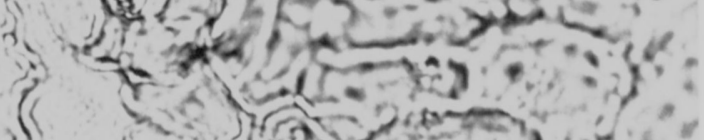

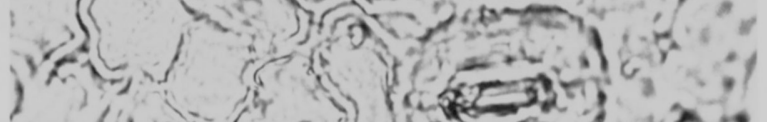
(16) 1 in
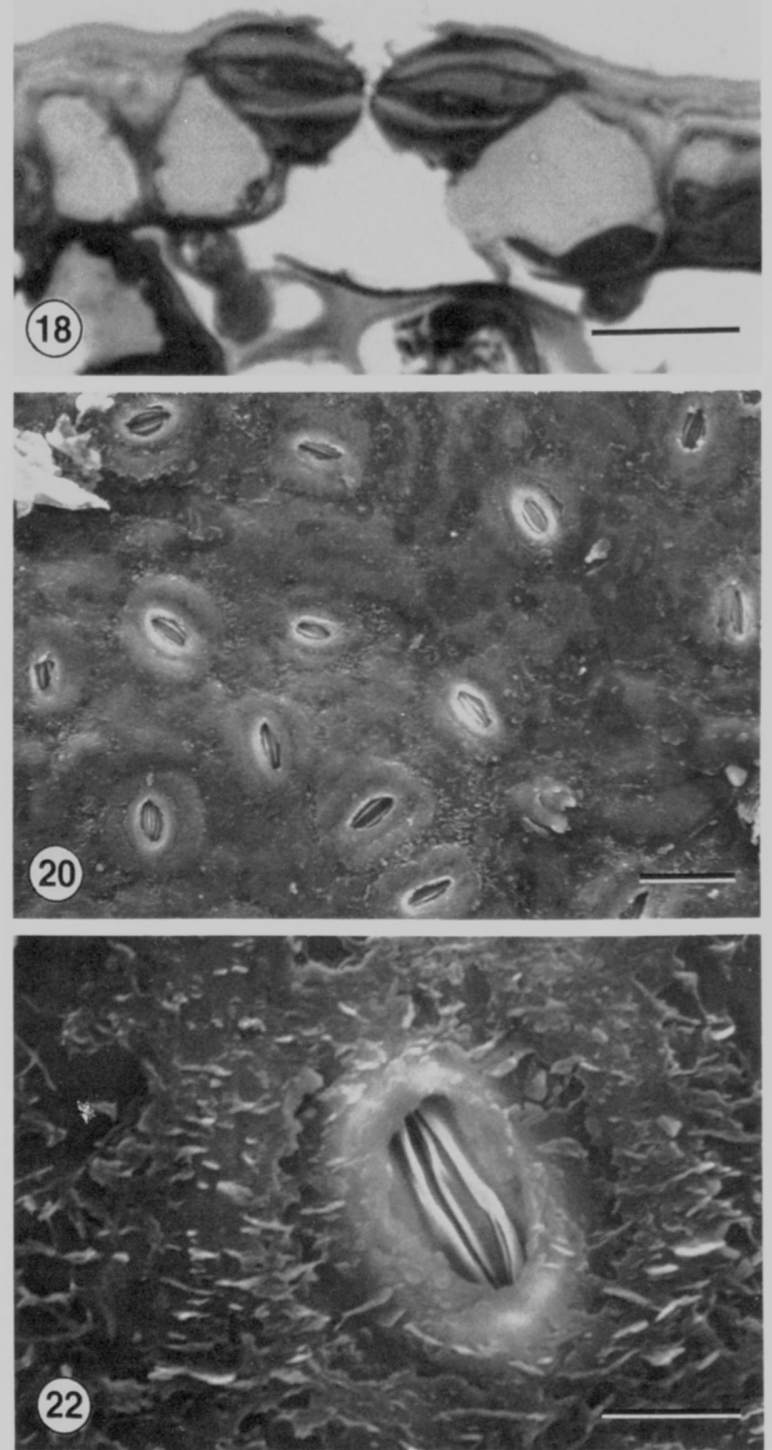
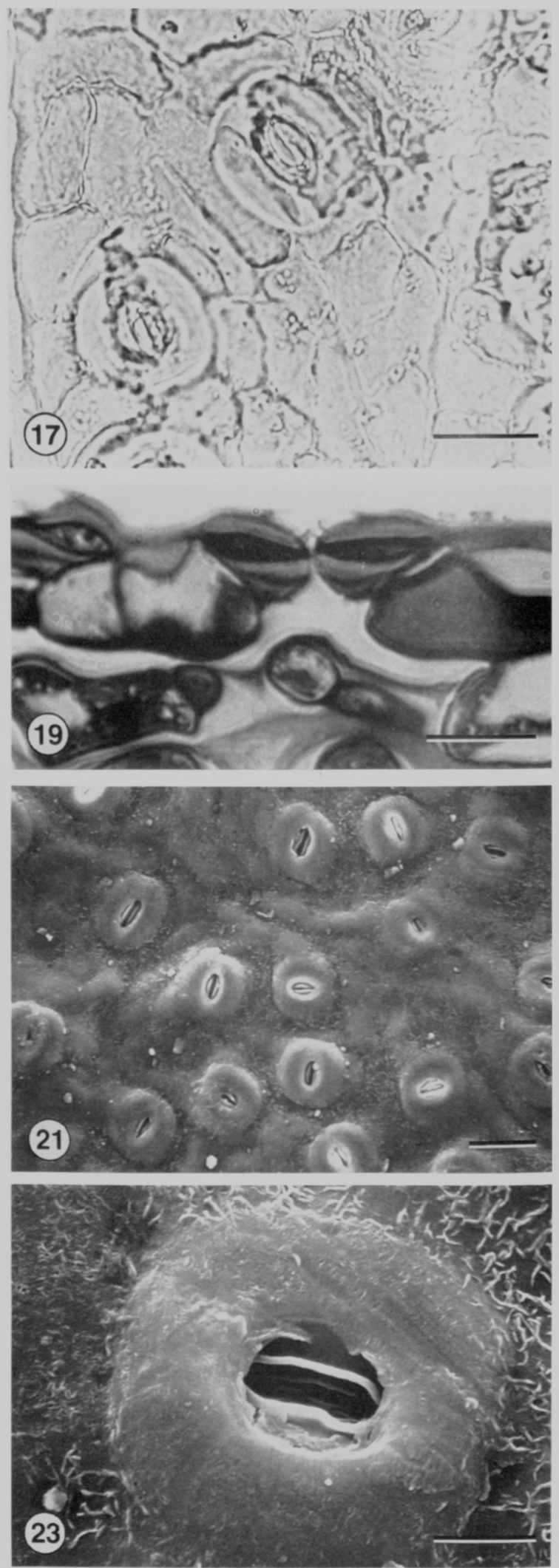

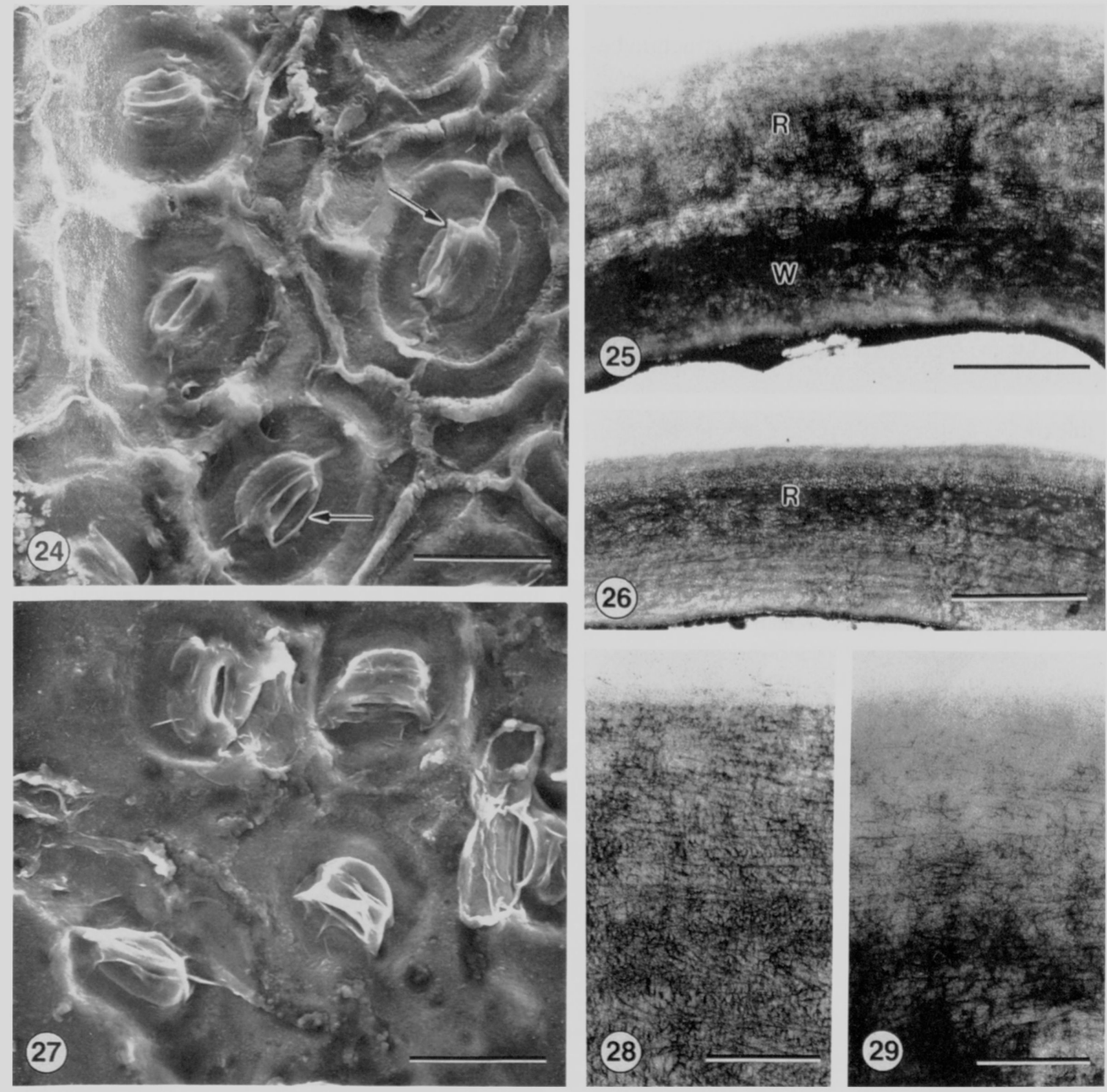

FIGS. 24-29.- Scanning and transmission electron micrographs of the abaxial epidermis of sun and shade leaves from Quercus velutina (sun leaves: figs. 24 and 25 ; and shade leaves: figs. 26 and 27). Fig. 24, Inner surface of isolated sun leaf CM showing anticlinal flanges around former positions of subsidiary cells and nonstomatal epidermal cells. Internal CMs that line substomatal cavities appear as folded flaps (arrows). Scale bar, $20 \mu \mathrm{m}$. Fig. 25, Transverse section of outer periclinal wall and CM of nonstomatal epidermal cell from sun leaf showing general ultrastructure; note cell wall proper $(W)$ and reticulate cuticular layer $(R)$. Scale bar, $2 \mu \mathrm{m}$. Fig. 26, Transverse section of outer periclinal wall and CM of nonstomatal epidermal cell from shade leaf showing general ultrastructure; note cell wall proper and reticulate cuticular layer $(R)$. Scale bar, $2 \mu \mathrm{m}$. Fig. 27 , Inner surface of isolated shade leaf CM showing relative absence of anticlinal flanges and overall less relief in comparison with sun leaf. Scale bar, $20 \mu \mathrm{m}$. Fig. 28, Detail of outer region from subsidiary cell CM showing reticulations that traverse the majority of the CM. Scale bar, $0.5 \mu \mathrm{m}$. Fig. 29, Detail of outer region from nonstomatal epidermal cell CM showing fewer reticulations and an amorphous cuticle proper. Scale bar, $0.5 \mu \mathrm{m}$.

FIGS. 16-23. - Light and scanning electron micrographs of the abaxial epidermis of sun and shade leaves from Quercus velutina (sun leaves: figs. 16, 18, 20, and 22; and shade leaves: figs. 17, 19, 21, and 23). Fig. 16, Surface of isolated sun leaf CM showing paracytic stomatal complexes and general size and morphology of guard cells, subsidiary cells, and nonstomatal epidermal cells. Scale bar, $20 \mu \mathrm{m}$. Fig. 17, Surface of isolated shade leaf CM with paracytic stomatal complexes. Compare size and morphology of guard cells, subsidiary cells, and nonstomatal epidermal cells with those of sun leaf. Scale bar, $20 \mu \mathrm{m}$. Fig. 18, Transverse section through sun leaf showing size of guard cells, nonstomatal epidermal cells, and thickness of overlying CM. Scale bar, $10 \mu \mathrm{m}$. Fig. 19, Transverse section through shade leaf showing size of guard cells, nonstomatal epidermal cells, and thickness of overlying CM. Scale bar, $10 \mu \mathrm{m}$. Fig. 20, Micromorphology of sun leaf surface showing smooth topography. Scale bar, $20 \mu \mathrm{m}$. Fig. 21, Micromorphology of shade leaf surface showing distinct topography and elevated appearance of stomatal complexes. Scale bar, $20 \mu \mathrm{m}$. Fig. 22, Detail of sun leaf stomatal complex showing abundant scaly epicuticular wax. Scale bar, $5 \mu \mathrm{m}$. Fig. 23, Detail of "elevated" shade leaf stomatal complex; note less epicuticular wax. Scale bar, $5 \mu \mathrm{m}$ 
There is a marked difference in ultrastructure between the adaxial epidermal cells of sun and shade leaves. The outer periclinal wall (cell wall proper) and associated CM of sun leaves are more than twice as thick as those of shade leaves, $5.9 \mu \mathrm{m}$ and 2.7 $\mu \mathrm{m}$, respectively (figs. 10-13; table 1). Both leaf types, however, possess a similar fine structural organization. The CM is composed of a reticulate region (cuticular region) and an outer amorphous layer (cuticle proper) covered with a layer of epicuticular wax (figs. 10, 13). The relative thicknesses of these components in sun and shade leaves are presented in table 1 .

The cell wall proper of both leaf types is similar in thickness, density (TEM), and the presence of faint lamellae (figs. 10, 13; table 1). It is delimited from the overlying $\mathrm{CM}$ at the point where wall lamellations cease and perpendicular reticulations, or fibrils, begin. Differences in thickness between the CM of sun and shade leaves can be primarily attributed to the reticulated layer. The CMs of sun leaves have reticulate regions which are about three times as thick as the corresponding layer in shade leaves (table 1). The reticulate layer is highly dense in the electron beam and composed of an inner, densely organized network of reticulations and an outer region of more sparsely distributed reticulations. Inner reticulate regions of sun leaves contain fibrils that are clearly less dense relative to the surrounding cuticular matrix in comparison with shade leaves (figs. 10,13). The amorphous layer is translucent in the electron beam and also adds to the increased thickness of sun leaf CMs. It may be up to twice as thick in sun leaves (figs. 14, 15; table 1).

Variation in CM thickness at anticlinal junctions is especially detectable at the ultrastructural level. The CM associated with anticlinal flanges and cuticular pegs in sun leaves is thicker and more distinct than those in shade leaves (figs. 11, 12; cf. figs. 8,9 ).

\section{ABAXIAL EPIDERMIS}

Abaxial epidermal cells are less tabular in surface view than adaxial cells and more or less irregular to slightly digitate in outline. Both sun and shade leaves are hypostomatic with paracytic stomatal complexes (figs. 16, 17). Sun leaves, however, have significantly more stomata per square $\mathrm{mm}$ than do shade leaves, averaging $528 \pm 22$ (SD; no. $=10)$ and $471 \pm 32(\mathrm{SD} ;$ no. $=10)$, respectively. Guard cells from both leaf types are similar in size, while nonstomatal epidermal cells have larger periclinal depths in sun leaves as compared to shade leaves (figs. 18, 19; table 1). A thicker abaxial CM on sun leaves is also seen by light microscopy (figs. 18, 19).

As with the adaxial surface, cell outlines are more topographically distinct on shade leaves. Stomata appear somewhat sunken on sun leaves and elevated on shade leaf surfaces (figs. 20, 21). Variation in relief is again due partly to epicuticular wax, which is more abundant on sun leaves (figs. $22,23)$. Epicuticular wax is predominantly scaly or flaky. This wax type has also been observed in several other individuals of Quercus velutina (HARDIN, personal communication). Sun leaves have obvious anticlinal flanges in comparison with shade leaves (figs. 24-27). Cuticular pegs on abaxial CMs from both leaf types are not as prominent as those on the adaxial surface (figs. 24, 27; cf. figs. 8, 9).

Ultrastructurally, the outer periclinal wall and CM of the abaxial epidermis are always thinner than those of the adaxial epidermis from each leaf type. The outer periclinal wall and associated CM from nonstomatal cells and subsidiary cells of sun leaves are typically 1.5 times thicker than those of shade leaves (figs. 25, 26) averaging $4.4 \mu \mathrm{m}$ and $2.9 \mu \mathrm{m}$, respectively (table 1 ). By comparison, this difference is proportionally less than that between sun and shade leaf adaxial CMs. The ultrastructure of this epidermal layer is similar in both leaf types as

FIGS. 30-36. - Transmission electron micrographs of the abaxial epidermis of sun and shade leaves from Quercus velutina (sun leaves: figs. 32 and 35; and shade leaves: figs. 34 and 36). Fig. 30, Transverse section through stomatal complex and underlying substomatal chamber from shade leaf. Scale bar, $10 \mu \mathrm{m}$. Fig. 31, Transverse section through sun leaf guard cell showing highly reticulate ultrastructure of outer periclinal $\mathrm{CM}$ and thick, amorphous $\mathrm{CM}$ over outer ledge (upper arrow), which extends to the large wall extension (lower arrow). Scale bar, $2 \mu \mathrm{m}$. Fig. 32, Detail of sun leaf CM over outer periclinal guard cell wall, same area as that in upper box in figure 30 . Note the cell wall proper $(W)$ and dense fibrils that traverse the entire CM in a radial fashion. Scale bar, $0.5 \mu \mathrm{m}$. Fig. 33, Detail of shade leaf stomatal aperture showing thick, amorphous CM, which extends to the large wall extension (arrow), and smaller protuberances lined by thin, amorphous CM in fore chamber of pore (FC). Note also the $\mathrm{CM}$ lining pore, and thicker, amorphous $\mathrm{CM}$, which lines inner walls bordering rear chamber of pore $(R C)$. Scale bar, $2 \mu \mathrm{m}$. Fig. 34, Detail of shade leaf CM over outer periclinal guard cell wall, same area as that in upper box in figure 30 . Note the cell wall proper $(W)$, dense, radially aligned fibrils that traverse the entire CM, and compare thickness with that of sun leaf. Scale bar, $0.5 \mu \mathrm{m}$. Fig. 35, Detail of sun leaf CM over inner periclinal guard cell wall between inner ledge and subsidiary cell, same area as that in lower box in figure 30 . Note the inner ledge (arrow) and relatively, thick amorphous CM with fibrils only sparsely distributed to median of CM. Scale bar, $0.5 \mu \mathrm{m}$. Fig. 36, Detail of shade leaf CM over inner periclinal guard cell wall between inner ledge and subsidiary cell from shade leaf, same area as that in lower box in figure 30 . Note the inner ledge (arrow) and thinner, amorphous CM with fibrils only sparsely distributed to median of CM. Scale bar, $0.5 \mu \mathrm{m}$. 


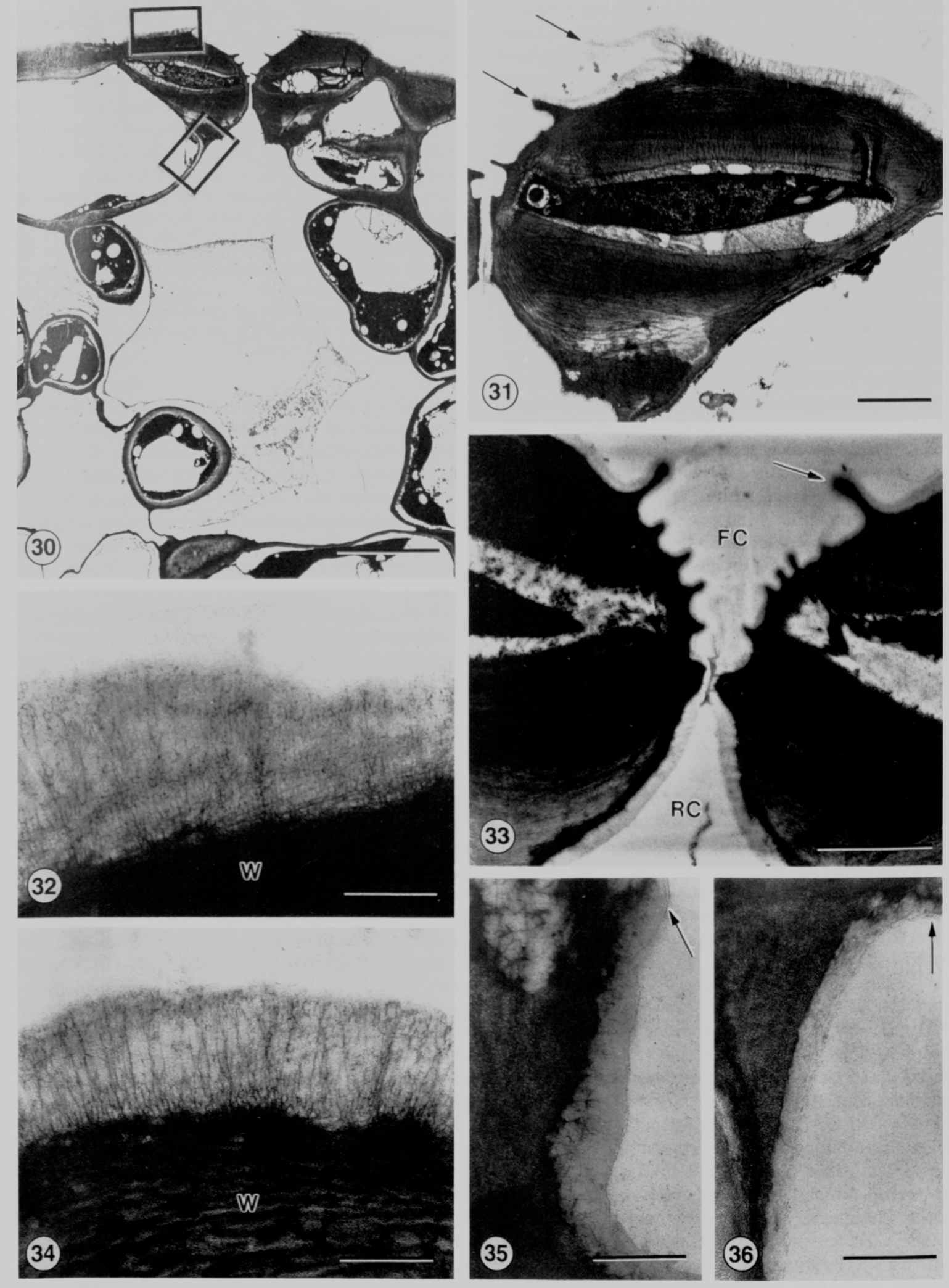


well as to the outer adaxial epidermal layer (i.e., cell wall proper, two-zoned reticulate region, amorphous layer, and epicuticular wax). Subsidiary cells, however, have reticulations that traverse the majority of the CM (fig. 28). Other nonstomatal epidermal cells have a more substantial amorphous layer (fig. 29). Regardless of cell type, the cell wall proper is typically the same thickness in sun and shade leaves; the overall thickness of sun leaf abaxial CMs is again predominantly due to variation in the reticulate region (figs. 25, 26; table 1).

Guard cells and associated substomatal chambers from both sun and shade leaves are similar at the ultrastructural level (figs. 30, 31). The CM over the outer periclinal wall of guard cells has an abundance of radially extending reticulations and is typically 1.5 times thicker in sun leaves (figs. 32, 34). It is proportionally as thick as CMs from nonstomatal and subsidiary cells of sun and shade leaves (table 1). The outer guard cell ledge has a thick CM that extends over the wall to a large protuberance (figs. 31, 33). From this extension to the pore (fore chamber of the pore), the wall has a variable number of smaller protuberances and is lined by a relatively thin $\mathrm{CM}$. The stomatal pore has a CM, as do guard cell walls bordering the rear chamber of the pore (fig. 33). Inner periclinal walls of subsidiary cells and spongy parenchyma cell walls exposed to the substomatal chambers are also lined by a CM. Internal CMs are thinner in comparison to outer CMs from respective leaf types, although internal CMs of sun leaves (fig. 35) are twice as thick as those that line the substomatal chambers of shade leaves (fig. 36; table 1). Internal CMs are also less reticulate than outer CMs. When reticulations occur, they are diffuse and only traverse ca. one-half of the CM (cf. figs. 35, 36 and 32, 34). Moreover, the thicker internal CM of sun leaves extends considerably deeper into substomatal chambers (fig. 37). Differences between the abaxial epidermises of sun and shade leaves are illustrated in figure 37.

\section{Discussion}

Holloway (1982) has provided a general classification for CMs, which includes six basic types, based on ultrastructural organization of transverse sections. The adaxial CM of Quercus velutina conforms to HoLloway's (1982) structural type 3 (outer region amorphous; inner region mainly reticulate), while the abaxial. $\mathrm{CM}$ exhibits both structural type 3 , on nonstomatal epidermal cells, and type 4 (all regions reticulate) on subsidiary and guard cells.

The cell wall proper of $Q$. velutina has tangentially oriented lamellae in the outer periclinal walls that are continuous with lamellae in anticlinal walls. CHAFE and WARDROP (1972) have reported cell wall lamellations in a number of other taxa. The orga-

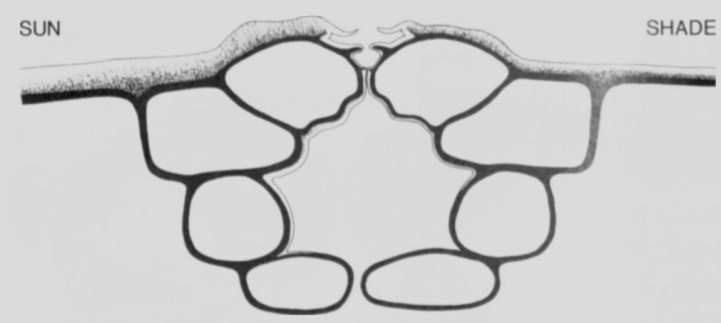

FIG. 37.-Idealized stomatal complex and associated substomatal chamber from sun and shade leaves of Quercus velutina. Left half of figure represents sun leaf and right half represents shade leaf. Figure compares relative thickness and general ultrastructure of outer periclinal CMs associated with nonstomatal epidermal cells (note amorphous layer), subsidiary cells (note extensive fibrils), and guard cells (note radial fibrils throughout) and relative thickness and depth of internal CM lining substomatal chamber.

nization of the reticulate region in both sun and shade leaves of $Q$. velutina $\mathrm{CMs}$ is consistent with most other plants in that the fibrillar density is greatest near the cell wall proper. Relative reticulate densities may be due in part to sectioning through different planes of the reticulum (HoLloWAY 1982), although we only examined true transverse sections of $Q$. velutina CMs. Reticulation density as seen with the TEM is generally the result of lead citrate and $\mathrm{KMnO}_{4}$ staining, however, WATTENDORFF and Holloway (1984) have suggested that reticulations may serve as channels from which $\mathrm{KMnO}_{4}$ diffuses. Furthermore, MÉrIDA et al. (1981) have shown that CMs from young leaves produce the opposite staining reaction of mature, fully expanded leaves. Regardless of the mechanism of the $\mathrm{KMnO}_{4}$ stain, all $Q$. velutina CMs were of the same age and exhibit similar fine structural organization. Sections stained only with uranyl acetate $(30 \mathrm{~min})$ and lead citrate $(30 \mathrm{~min})$ also possess a reticulum that is denser at the junction with the cell wall proper and a translucent (TEM) cuticle proper. The most prominent difference in comparison with sections also stained with $\mathrm{KMnO}_{4}$ is an overall decrease in density as seen in the electron beam.

Clearly the most significant ultrastructural differences between sun and shade leaves of $Q$. velutina are thickness and degree of density within the reticulate region. The reticulate region of sun leaves has more reticulations and has apparently undergone more cutinization and cell wall expansion in the inner reticulate zone as indicated by its less dense nature. Earlier reports of increased production of cellulose, pectin, cutin, and cuticular waxes in plants subjected to high irradiances (TRIBE et al. 1968; GiUlini-Cordera 1970; EsPELIE et al. 1979) provide additional indirect evidence for this hypothesis. Interestingly, degree of expansion of the cuticular layer (reticulate region in $Q$. velutina) and thickness of the overall epidermal cell wall and 
associated CM may vary depending on laminal distance from the leaf base (RIEDERER and SCHÖNHERR 1988). This, however, is not a factor regarding thickness variation of the reticulate layer in sun and shade leaves of $Q$. velutina because we examined leaf tissue from the same laminal positions of each leaf type.

An additional parameter to consider when evaluating CMs at the fine structural and micromorphological levels is the loss of cuticular materials during preparation techniques. Fixations in glutaraldehyde and osmium, as well as dehydration in polar solvents are known to variously extract and morphologically alter the chemical constituents of the CM, particularly cuticular and epicuticular waxes (RENTSCHLER 1979; REED 1982). Furthermore, MAYEUX and JORDAN (1987) have documented up to $50 \%$ losses of epicuticular wax as a result of natural rainfall. It is possible that sun and shade leaves of $Q$. velutina have been altered with respect to their epicuticular wax during SEM and TEM preparation. The effects, however, should be proportional in each leaf type because they were prepared in an identical fashion. If epicuticular wax on $Q$. velutina leaves were susceptible to rainfall, one would expect sun leaves, because of their position in the canopy, to lose more wax. Shade leaves on the other hand, would be more protected from epicuticular wax removal by rainfall due to barrier effects of the tree crown. Nevertheless, sun leaves have more epicuticular wax on both adaxial and abaxial surfaces. Although sun leaves possess more epicuticular wax, other cuticular components per se primarily contribute to variation in CM surface topography as seen with the SEM. AL-JAFF et al. (1982) found that such topographic features of sun and shade leaves affect uptake of herbicide.

The fact that sun leaf $\mathrm{CMs}$ were found to be thicker than those of shade leaves at the ultrastructural level in $Q$. velutina contradicts the findings of Hull et al. (1975) and REED and TuKEY (1982). Their studies examined the correlative environmental effects of both light intensity and temperature on experimentally grown plants. It is clear that temperature-induced differences in $\mathrm{CM}$ thickness are more pronounced than irradiance effects and that temperature range is also a factor. Sun and shade leaves in our investigation have been taken from a naturally grown tree and were subject only to ambient environmental conditions.

MéRIDA et al. (1981) have shown cuticular transpiration to be independent of CM thickness and suggested that the chemical nature of the cuticle proper has the greatest effect on minimizing transpiration. The effect of light on synthesis and isomer composition of cutins (ESPELIE et al. 1979) may strengthen this hypothesis with respect to sun and shade leaves. Nevertheless, naturally grown sun and shade leaves of $Q$. velutina have differentially thickened CMs. Furthermore, transpiration rates of sun grown leaves are often higher than shade grown leaves (SESTÁK et al. 1978). Increased water loss from sun leaves is certainly due in part to a greater number of stomata and consequential evapotranspiration. The ultrastructural organization of guard cell walls and CMs, however, may also play a role in increasing peristomatal transpiration (MAIERMAERCKER 1983; SACK 1987). The fine structure of guard cell CMs of $Q$. velutina exhibits a marked difference from subsidiary cells and other nonstomatal epidermal cells. Guard cell CMs from both sun and shade leaves of $Q$. velutina lack an amorphous cuticle proper and have dense, radially aligned fibrils that reach the CM surface. It is difficult to assess the relative fibrillar densities of respective leaf types without a quantitative evaluation. Such an evaluation may help elucidate differential transpiration rates because transcuticular fibrils may function in peristomatal transpiration (SACK and PAOLILlo 1983). Interestingly, in another species of Quercus, $Q$. robur, guard cells are lined externally by only a partial $\mathrm{CM}$ and have been shown to be a possible site of water loss (APPLEBY and DAVIES 1983). Variation of the internal CMs lining substomatal chambers may also have functional significance. Sun leaves of $Q$. velutina have greater internal CMs with regard to both thickness and extensiveness in the chambers. Internal $\mathrm{CMs}$ are known from other angiosperms and bryophytes and have been suggested as additional barriers to transpirational loss (SACK and PAOLILlO 1983; WULLSCHLEGER and OOSTERHUIS 1989).

Our investigation provides detailed information on $\mathrm{CM}$ ultrastructure relative to variable irradiance levels under natural environmental conditions. Fine structural and micromorphological data from sun and shade leaf CMs augment other studies of ecological anatomy and morphology that have been conducted by both light and electron microscopy. Our study adds to the database on general CM ultrastructure and, in particular, guard cell CMs. $\mathrm{Cu}-$ ticular membranes of guard cells with reticulations that reach $C M$ surfaces as in $Q$. velutina are unequivocally known from very few taxa (SACK 1987), none of which are angiosperms.

\section{Acknowledgments}

We thank F. D. SACK for valuable discussions and comments on the manuscript. This study was supported in part by a Grant-in-Aid of Research from Sigma Xi, the Scientific Research Society to J. M. OsBorn and the National Science Foundation (DPP-8716070). 


\section{LITERATURE CITED}

Al-JaFF, D. M. A., G. T. COOK, K. E. CARR, and H. J. DuNCAN. 1982. Further studies on bracken morphology in relation to herbicide uptake. Pages 293-301 in D. F. CUTLER, K. L. Alvin, and C. E. Price, eds. The plant cuticle. Academic Press, London.

Alvin, K. L., and M. C. Boulter. 1974. A controlled method of comparative study for taxodiaceous leaf cuticles. Bot. J. Linn. Soc. 69:277-286.

APPleby, R. F., and W. J. DaviES. 1983. The structure and orientation of guard cells in plants showing stomatal responses to changing vapour pressure differences. Ann. Bot. 52:459-468.

BAKER, E. A. 1974. The influence of environment on leaf wax development in Brassica oleracea var. gemmifera. New Phytol. 73:955-966.

BJöRKMAN, O. 1981. Responses to different quantum flux densities. Pages 57-107 in O. L. Lange, P. S. Nobel, C. B. OSMOND, and H. ZIEGLER, eds. Physiological plant ecology. Vol. 1. Responses to the physical environment. SpringerVerlag, Berlin.

Blue, M. P., and R. J. Jensen. 1988. Positional and seasonal variation in oak (Quercus; Fagaceae) leaf morphology. Am. J. Bot. 75:939-947.

ChaFE, S. C., and A. B. Wardrop. 1972. Fine structural observations on the epidermis. I. The epidermal cell wall. Planta 107:269-278.

Dengler, N. G. 1980. Comparative histological basis of sun and shade leaf dimorphism in Helianthus annuus. Can. J. Bot. 58:717-730.

EsAU, K. 1965. Plant anatomy. 2d ed. Wiley, New York.

Espelie, K. E., B. B. Dean, and P. E. Kolattukudy. 1979. Composition of lipid-derived polymers from different anatomical regions of several plant species. Plant Physiol. 64:1089-1093.

FAGERBERG, W. R. 1988. The effect of neutral shade on the structure of mature, sun-acclimated palisade cells of Helianthus annuus L. II. 3-day exposure. BOT. GAZ. 149:295-302.

GiUlinI-CoRDERA, P. 1970. Analisi su cuticole fogliari: Dosamento istofotometrico di componenti culticolari in piante mantenute in diverse intensita luminose. Atti Accad. naz. Lincei Rc. Cl. Sci. Fis. Mat. Nat., ser. 8. 49(6):427-430.

HANSON, H. C. 1917. Leaf structure as related to environment. Am. J. Bot. 4:533-560.

Holloway, P. J. 1982. Structure and histochemistry of plant cuticular membranes: an overview. Pages $1-32$ in D. F. Cutler, K. L. Alvin, and C. E. Price, eds. The plant cuticle. Academic Press, London.

HoRn, H. S. 1971. The adaptive geometry of trees. Princeton University Press, Princeton, N.J.

Hull, H. M., H. L. Morton, and J. R. Wharrie. 1975. Environmental influences on cuticle development and resultant foliar penetration. Bot. Rev. 41:421-452.

Hull, H. M., F. W. Went, and C. A. Bleckmann. 1979. Environmental modification of epicuticular wax structure of Prosopis leaves. J. Arizona-Nevada Acad. Sci. 14:39-42.

KausCh, W., and W. HaAs. 1965. Chemische unterschiede zwischen sonnen- und schattenblättern der blutbuche (Fagus sylvatica L. cv. atropunicea). Naturwissenschaften 52:214215.

MAIER-MAeRCKER, U. 1983. The role of peristomatal transpiration in the mechanism of stomatal movement. Plant Cell Environ. 6:369-380.
Martin, J. T., and B. E. JUNIPER. 1970. The cuticles of plants. St. Martin's, New York.

MAYEUX, H. S., JR., and W. R. JoRDAN. 1987. Rainfall removes epicuticular waxes from Isocoma leaves. BOT. GAZ. 148:420-425.

MÉrida, T., J. SchönherR, and H. W. SCHMidT, 1981. Fine structure of plant cuticles in relation to water permeability: the fine structure of the cuticle of Clivia miniata Reg. leaves. Planta 152:259-267

NiKLAS, K. J. 1989. The effect of leaf-lobing on the interception of direct solar radiation. Oecologia 80:59-64

REED, D. W. 1982. Wax alteration and extraction during electron microscopy preparation of leaf cuticles. Pages 181-195 in D. F. Cutler, K. L. Alvin, and C. E. Price, eds. The plant cuticle. Academic Press, London.

REED, D. W., and H. B. TUKEY, JR. 1982. Light intensity and temperature effects on epicuticular wax morphology and internal cuticle ultrastructure of carnation and brussels sprouts leaf cuticles. J. Am. Soc. Hort. Sci. 107:417-420.

RENTSCHLER, I. 1979. Zur Präparation der wachsschicht von pflanzenblättern für die elektronenmikroskopie. Micros. Acta 82:47-52.

RIEDERER, M., and J. SCHÖNHERR. 1988. Development of plant cuticles: fine structure and cutin composition of Clivia miniata Reg. leaves. Planta 174:127-138.

Rowley, J. C., and D. T. Moran. 1975. A simple procedure for mounting wrinkle-free sections on formvar-coated slot grids. Ultramicroscopy 1:151-155.

SACK, F. D. 1987. The development and structure of stomata. Pages 59-89 in E. ZeIger, G. D. FarQUHAR, and I. R. COWAN, eds. Stomatal function. Stanford University Press, Stanford, Calif.

SACK, F. D., and D. J. PAOLILlo, JR. 1983. Stomatal pore and cuticle formation in Funaria. Protoplasma 116:1-13.

Sesták, Z., J. Solárová, J. Zima, and J. Václavík. 1978. Effect of growth irradiance on photosynthesis and transpiration in Phaseolus vulgaris L. Biologia Plantarum 20:234 238.

SolárovÁ, J., and J. Pospiślllová. 1988. Stomatal frequencies in the adaxial and abaxial epidermis of primary bean leaves affected by growing irradiances. Acta Universitatis Carolinae-Biologica 31:101-105.

Tribe, I. S., J. K. Gaunt, and D. W. Parry. 1968. Cuticular lipids in the Gramineae. Biochem. J. 109(2):8-9P.

Venable, J. H., and R. Coggeshall. 1965. A simplified lead citrate stain for use in electron microscopy. J. Cell Biol. 25:407.

VOGEL, S. 1968. "Sun leaves" and "shade leaves": differences in convective heat dissipation. Ecology 49:1203-1204.

WatTENDORFF, J., and P. J. Holloway. 1984. Periclinal penetration of potassium permanganate into mature cuticular membranes of Agave and Clivia leaves: new implications for plant cuticle development. Planta 161:1-11.

WILD, A., and G. WOLF. 1980. The effect of different light intensities on the frequency and size of stomata, the size of cells, the number, size and chlorophyll content of chloroplasts in the mesophyll and the guard cells during the ontogeny of primary leaves of Sinapis alba. Z. Pflanzenphysiol. 97:325-342.

Wullschleger, S. D., and D. M. Oosterhuis. 1989. The occurrence of an internal cuticle in cotton (Gossypium hirsutum L.) leaf stomates. Environ. Experiment. Bot. 29:229-235. 